\title{
ESP: A Needs Analysis of Maritime English at Polimarin
}

\author{
Deri Herdawan ${ }^{*}$, Kirtyana Nindita, Ari Ani Dyah Setyoningrum \\ Politeknik Maritim Negeri Indonesia \\ deriherdawan@polimarin.ac.id
}

\begin{abstract}
As an archipelagic country, Indonesia has long been known for its marine potential. This potential comes with new challenges, one of them being language problem. In this regard, English shows its prominent role as the international language to bridge communications. This research provided a needs analysis to identify the "necessities", "lacks", and "wants" in relation with English usage in maritime sector, specifically for those conducting internship at international ships. A qualitative approach and a descriptive design were applied in this research. The respondents consisted of 19 students of Polimarin who had completed internship at international ships, selected through total sampling technique. Their responses were collected by a questionnaire, complemented by interview. The collected data were then processed through a model consisting of four stages; data collection, data reduction, data display, and conclusion drawing. The "necessities" analysis revealed speaking and vocabulary as the most needed language skill and component. The "lacks" analysis showed that the syllabus used pays attention to English language skills and components evenly and that some respondents were underprepared before doing internship. The "wants" analysis came up with the simple present tense and the simple past tense as the most wanted tenses to master, pronouns as the most wanted grammatical feature and passive voice as the least wanted, all language functions evenly wanted, and group discussion as the most preferred learning activity. In conclusion, syllabus revision is due to improve the quality of English learning by accommodating the students' "necessities", "lacks", and "wants".
\end{abstract}

Key words: esp, maritime english, needs analysis 


\section{A. INTRODUCTION}

As an archipelagic country, Indonesia has long been known for its marine potential. However, it is only in the last few years that the maritime sector of this country has started to become active. This is evidenced by the increasing number of Indonesian seafarers in each year. Based on data from the Human Resources Development Agency (BPSDM) of the Ministry of Transportation, this number increased sharply from 78,000 seafarers in 2010 to 480,000 in 2014 (Guritno, 2017) and continues to increase to 1,200,000 seafarers in 2020 (Rantung, 2021). The government has shown its support to this positive trend by issuing Presidential Regulation of the Republic of Indonesia Number 82 of 2019 which brings changes in the form of the Directorate General of Vocational Education operating under the Ministry of Education and Culture.

The new potential always comes with new challenges, as well as the case in the maritime sector. Several challenges that must be faced for those who want to work in the maritime world include complex international maritime laws and regulations, potentially high risks on work safety and health (Rahman et al., 2017), unfriendly working hours (Syahdian, 2017), and communication problem (Guritno, 2017) which becomes the topic of discussion in this article.

The maritime world is one sector where language plays a bigger role, especially on an international scale. The first reason is that communication is very crucial and decisive factor in various process of the maritime sector, such as reporting location, requesting assistance, making emergency call, and others. Secondly, the situation in which various people from coming various countries come into contact requires a lingua franca, which is a language used for communication among groups that have different mother tongues (Sebba, 1997). This is where English, which is an international language, comes under the spotlight. 
The urgency of acceptable English competence for students wanting to take part in the maritime sector is fully realized by Politeknik Maritim Negeri Indonesia (Polimarin). This institution, which aims to produce prospective seafarers through its technical and nautical programs, includes English in its curriculum. However, due to the very high number of subjects in the existing curriculum, the quantity or duration of English learning is still insufficient, leading to sub-optimal results. To mitigate this situation, it is the quality of learning that must be optimized.

Improvement in English learning for those students can be started by identifying their learning as English for Specific Purposes (ESP) rather than general English due to their specific need of English in maritime context. Problems and limitations are always present in English learning, but ESP functions to narrow them down (Hutchinson \& Waters, 1987). They also added that in ESP, there are target needs and learning needs analyses. Of the two, the former is more focused on the students by carefully analyzing their "necessities", "lacks", and "wants" in order to identify which specific language skills are needed in which specific situations, effectively removing the burden from the unnecessary ones.

English learning is an ongoing process and can indeed be done while students or graduates are already in internship or work place that demand mastery of the language. However, many companies set a certain level of English competence in order to join them in the first place. In addition, lacking English competence at the start of their internship or work will hinder their performance and assessment. Both of these points again emphasize the need for ESP needs analysis for their English learning. Through ESP needs analysis, it is expected that the students or graduates have sufficient required English competence as a starting point. 
Based on this background, this research was conducted taking the title "ESP: A Needs Analysis of Maritime English at Polimarin". Specifically, this research attempted to identify the "necessities", "lacks", and "wants" of those students.

\section{B. LITERATURE REVIEW}

\section{English Competence}

The term competence covers a very broad area. In the psychology dictionary, it is defined as capacity, skills, or the ability in doing something correctly and effectively (Colman, 2014). Here, English competence is viewed from the mastery of English receptive and productive skills as well as English language components. The receptive skills consist of listening and reading. They are referred to as receptive skills because through listening and reading, information is received, decoded, and processed to obtain meaning. While the productive skills of speaking and writing is called productive because they generate products in the form of messages that are conveyed to the recipients. Meanwhile, language components, such as vocabulary and grammar, exist to support the use of those language skills.

Many experts have tried to define each of the language skills. Listening is described as the process of receiving the message conveyed by the speaker, then breaking and rearranging the message conveyed, negotiating the information or meaning contained in it, ending with responding to the message (Rost, 2011). Meanwhile, reading is a complex conscious and unconscious mental process in which the reader uses various strategies to reconstruct the meaning that is considered intended by the author, based on information from the text and from the reader's previous knowledge (Mikulecky, 2011). Speaking itself is defined as an interactive process in constructing meaning that involves the production, reception, and processing of information (Burns \& Joyce, 1997). Writing is a 
process of finding and organizing ideas, expressing the ideas on paper, as well rearranging and revising those ideas (Mayers, 2005).

The four language skills above cannot stand alone as they must be supported by language components for their use in communicating. In this research, two specific language components were included in the analysis and discussion of the research. The first is vocabulary which means all available words in a language. While the second is grammar which refers to the system that regulates how phrases and sentences in a language are arranged. Wilkin in (Thornbury, 2002) explained the importance of these two language components in communication, in which he stated that only a little can be conveyed without grammar, and nothing can be conveyed without vocabulary.

\section{English for Specific Purposes (ESP)}

ESP is an approach to English learning by taking heavy consideration on the specified purposes of acquiring English. In their book, (Hutchinson \& Waters, 1987) defines ESP as an approach to language learning that bases all its components, such as materials and methods, on the goals to be achieved by students. As it upholds the principle of a learner-centered approach, the scope of ESP is narrower than English learning in general. Usually, ESP learning is closely related to the need to communicate in English in relation to work, and not just an interest in English language itself.

Overall, the use of ESP as an approach in designing learning goes through several stages and consists of a lot of components. These stages are flexible and cyclical so that they can always change as student goals change or through feedback and evaluations carried out. 


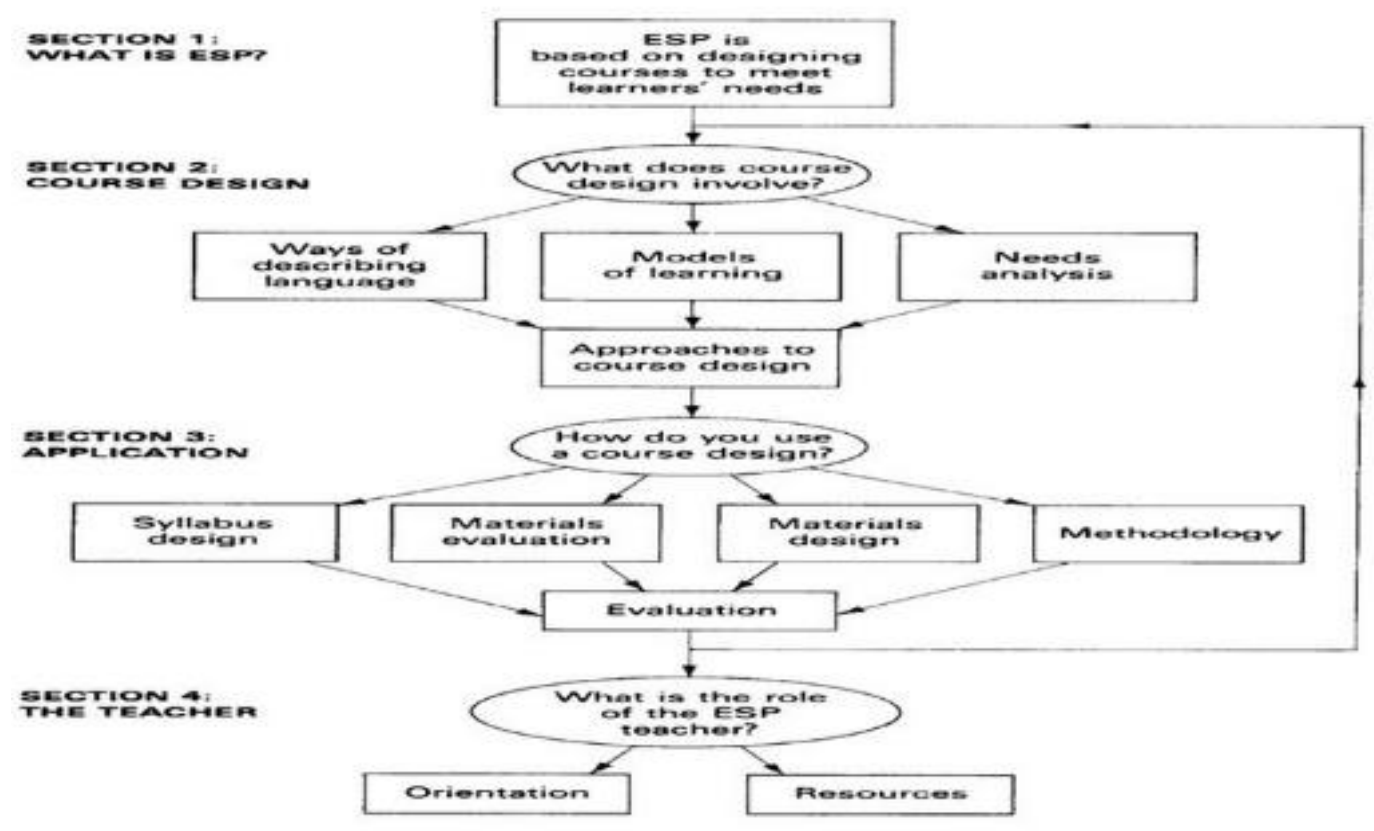

Figure 1.ESP Outline (Hutchinson \& Waters, 1987)

Two of the many components shown in the diagram above will be discussed further in the next sub-chapters, namely needs analysis (second stage) and syllabus design (third stage).

\section{Needs Analysis}

Needs analysis is a very inherent characteristic or identity of an ESP. A needs analysis is defined an attempt to identify certain language skills or components, which are needed by a particular group of learners in order to achieve their learning goals (Basturkmen, 2010). This definition is then supported by another expert expressing similar notion that a needs analysis is done to answer the "what" and "how" of learning (Flowerdew, 2013).

A needs analysis is the first step in a series of processes in ESP. this analysis will be continued by curriculum design, selection of materials, selection of learning methods and techniques, and ends with evaluation (Flowerdew, 2013). Although 
the above statement mentions the initial and the final stages, this series of processes is not something linear, but continuous. Feedback will always appear at each stage. Each feedback can form a new needs analysis or add to an existing one. This can happen because as learning progresses, teachers know more and more what their students need, what methods are right for them, how they want to be evaluated, whether there is a shift in needs, and how the shift in needs affects all other stages.

Needs analysis can be categorized into two different aspects; namely target needs and learning needs (Hutchinson \& Waters, 1987). A further explanation was also provided by them that target needs mean what students need in the target situation, consisting of three sub-aspects. Firstly, the "necessities", which are what students need in order to work in the target situation. Secondly, the "lacks", which refer to what the student currently do not know in order to work in the target situation. Thirdly, the "wants", which are students' opinions about what they want or need in the target situation. Meanwhile, learning needs refer to anything that facilitate the students in order for them to learn, such as methods, learning materials, their personal background, and others.

\section{Syllabus}

The term "syllabus" is closely related to the term "curriculum". The differences between the two have been explained by several researchers. One of them is (Hoesny, 2013) who conducted research by raising the topic of syllabus and curriculum development. In her research, she mentions that the curriculum is the outline of an educational or training course. While the syllabus is explained as a fraction of the curriculum, the smaller components that can be learned. It can be said that the syllabus is a derivative of the curriculum which includes several specific things such as descriptions, objectives, materials, methods, and assessments. It is worth-noted that a curriculum can produce several kinds of 
syllabus which vary depending on various factors, one of which is the needs analysis.

\section{RESEARCH METHOD}

A qualitative approach was implemented in this research. This approach tries to analyze its research object as it is (Sugiyono, 2016). More specifically, a descriptive design was used in which the research findings were presented in the form of an overview or description.

The research subjects were students of Polimarin with the inclusion criteria of: (1) students and graduates who are from the Engineering or Nautical study program and (2) students who had completed an internship at international ship. The strict selection of internships and the relatively new cooperation between Polimarin and the international company where the students did their internship lead to small number of students fulfilling the inclusion criteria. Due to this circumstance, the total sampling technique was used, obtaining 19 students and graduates as respondents.

Data collection was done primarily by questionnaire. It consists of 17 questions to gather data regarding the "necessities" (7), "lacks" (6), and "wants" (4). Subsequent interview sessions were conducted to those whose responses were unclear or in need for confirmation, serving as data validation. In addition, this research made use of some documents in its instrument design and analysis, in the form of syllabus used for teaching English at Polimarin. The data were processed through several stages of the interactive model. The stages consist of data collection, data reduction, data display, and lastly conclusion drawing (Miles \& Huberman, 1994). 


\section{FINDINGS AND DISCUSSION}

\section{Necessities}

\section{Overall English}

Concerning the importance of English in their internship, their responses were straightforward that the ability to communicate using English was crucial to them. The majority of them (17 respondents) stated that English was 'very important' and the other 2 respondents provided slightly lower emphasis or considered English as "important". No respondent replied with "slightly unimportant' or "unimportant" in this matter.
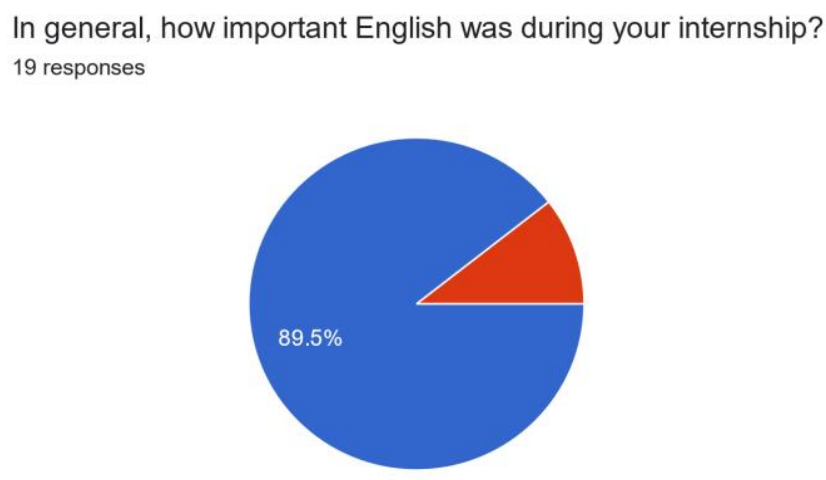

Figure 2. Overall English "Necessities"

It is a widely known and discussed that English is an international language (Sharifian, 2009). In maritime industry, specifically in international ships, the international language has been proven very crucial. Various people from all different parts of world work together in an understandably challenging environment. There are significantly more risks in working on board rather than most occupations on land. Throw in the miscommunication factor due to language problems, those risks could rise exponentially. Therefore, this line of work really needs English to make everything running well. 
A further emphasis is put on by the fact the respondents were from Indonesia, joining international ships for experience. The respondents were not afforded time to settle in using any other language. Bahasa Indonesia was never an option as none spoke the language on board. For the same reason, code switching did not work either like it was during English learning at Polimarin. Therefore, they could only rely on their English competence.

\section{English Language Skills and Components}

Having established the importance of English in general for the internship, the next 6 questions attempted to break this matter further by examining 4 language skills and 2 language components.

Table 1. Summary of "Necessities" Results

\begin{tabular}{ccccc}
\hline Language Skills & \multicolumn{4}{c}{ Responses (\%) } \\
\cline { 2 - 5 } and Components & Very Needed & Needed & Unneeded & Very Unneeded \\
\hline Listening & 84.2 & 15.8 & 0 & 0 \\
\hline Speaking & 89.5 & 10.5 & 0 & 0 \\
\hline Reading & 42.1 & 57.9 & 0 & 0 \\
\hline Writing & 26.3 & 73.7 & 0 & 0 \\
\hline Vocabulary & 73.7 & 26.3 & 0 & 0 \\
\hline Grammar & 21.1 & 73.7 & 5.2 & 0 \\
\hline
\end{tabular}

The questions focused on speaking and listening obtained almost identical responses from the respondents with the previous one regarding English in general. A large chunk of them (16 respondents) considered speaking as a "very needed' skill, 3 respondents believed this skill was "needed", and none thought it as "unneeded" or "very unneeded". As for listening, no respondent thought listening as "unneeded', let alone "very unneeded". 2 respondents considered this skill as "needed" and 17 respondents claimed it as "very needed".

The nest two questions inquired about reading and writing, whether these particular skills were of importance in their internship. There was a drop of emphasis in reading skill compared to the previous two skills (speaking and 
listening), even though no respondent gave "unneeded" or "very unneeded" as their answer. Only 8 respondents considered reading as "very needed" with more of them (11 respondents) thought this skill as merely "needed". A further drop of emphasis was found in writing skill. Of the four English skills, writing was the least used one during their internship. However, still no respondent provided negative responses in the categories of "unneeded" or "very unneeded". 5 respondents thought this skill was "very needed" and a significantly higher number of respondents (14) considered this as only "needed".

Moving on from language skills, the next two questions asked about two of the language components; vocabulary and grammar. The mastery of vocabulary received particularly strong emphasis from the respondents. Of course no respondent gave "unneeded" or "very unneeded" answers. 5 respondents provided "needed" responses. Lastly, 14 respondents thought this language component highly, as they considered it as "very needed". Meanwhile, grammar received the most number of 'negative' responses from the respondents, especially when compared to the other language component discussed in this research. There was one respondent who considered this language component as "unneeded", the first response ever on this category. A large number of them (14 respondents) thought grammar mastery as "needed" while only 4 respondents considered it as "very needed".

Questions regarding the importance of listening and speaking skills obtained extremely similar responses. This is understandable as both belong to the English spoken communication skills and one is often used in accompany with another. Monologues rarely occur in ship setting, while dialogues dominate the communication taking place on board. However, the questions about the importance of reading and writing obtained more imbalanced responses, with reading getting more emphasis. The reason is because these two skills do not 
necessarily see usage at the same time. Writing is very often used without the need for reading and reading does not always need writing.

In overall, the spoken communication skills gathered more emphasis than its written counterparts. The majority of daily communication takes place in spoken form and that is why it is considered the most important (Kuning, 2019). The same case goes in the maritime world. During their work hours, interns are mostly subjected to various instructions and guidance (listening), to which they would respond with actions or questions (speaking). In addition, communication in afterwork hours are also done in spoken manner between ship crews. Meanwhile, reading is mainly done only at the initial stage of internship where various manuals or standard operating procedures are given for them to read. Making reports, if any, is handled by their supervisor. This is reflected by the results in which there were more respondents putting emphasis in reading compared to writing.

As for the language components of vocabulary and grammar mastery, the former obtained more positive responses from the respondents. As a famous quote by Wilkin in (Thornbury, 2002) "few can be said without grammar, but nothing can be conveyed without vocabulary. Provided within a certain context, the actual meaning of an utterance with incorrect grammar can still be understood. However, nothing can be understood if the utterance lacks words, especially the content words. Moreover, spoken communication pays less attention to grammar than written communication does. A single word sentence frequently occurs and is often acceptable in spoken communication setting. Meanwhile, written communication is restricted by its requirement of correct grammar, especially in formal setting. 


\section{Lacks}

Table 2. Summary of "Lacks" Results

\begin{tabular}{ccccc}
\hline Language Skills & \multicolumn{4}{c}{ Responses (\%) } \\
\cline { 2 - 5 } and Components & Very Good & Good & Poor & Very Poor \\
\hline Listening & 10.5 & 68.4 & 21.1 & 0 \\
\hline Speaking & 15.8 & 73.7 & 10.5 & 0 \\
\hline Reading & 21.1 & 73.7 & 5.2 & 0 \\
\hline Writing & 10.5 & 73.7 & 15.8 & 0 \\
\hline Vocabulary & 10.5 & 73.7 & 15.8 & 0 \\
\hline Grammar & 5.3 & 68.4 & 26.3 & \\
\hline
\end{tabular}

In regards of English spoken communication skills, which involve listening and speaking, the majority of the respondents thought that their skills were adequate to conduct internship. More than half (13 and 14 respondents for listening and speaking, respectively) considered themselves as having "good" competence. The rest of the respondents were fairly split between "very good" and "poor" categories. Meanwhile, there was no respondent had "very poor" proficiency in English spoken communication skills.

As for English written communication skills, there was similar distribution among the respondents. Most of the respondents (both 14 respondents for reading and writing) believed that they had "good" written communication skills by the time they started conducting their internship. In addition, there were more respondents who had "very good" reading proficiency (4 respondents) compared to writing proficiency ( 2 respondents). This is natural as writing is widely known as the most difficult skill to master. No respondent had "very poor" category of English written communication proficiency.

Moving on to the respondents' mastery in English language components, there was a similar trend from the previous results. In vocabulary mastery, 2 respondents had "very good" mastery, 14 respondents came up with "good" mastery, 3 respondents belonged to "poor" category, and no respondent had "very 
poor" mastery. As for grammar mastery, which is considerably more difficult to master, there were more respondents (5) who considered themselves as having "poor" mastery. There was only one respondent with "very good" category, with most of them (13 respondents) believed that they had "good" grammar mastery. Just like the previous cases, no respondent had "very poor" mastery.

The six questions in the "lacks' section attempted to find out how the respondents saw themselves in respect of their English proficiency just before they started their internship. This would be extremely useful to assess whether the learning process provided by Polimarin has served the students well in preparing them to face the stiff competition in the post-education world.

With more than half of the respondents categorizing themselves as having "good" proficiency in all English skills and components, it can be said that their learning in Polimarin was quite successful. This is the opposite of the results of a previous research conducted in Polimarin, in which the graduates had unsatisfactory proficiency (Rahayuningsih, 2020). Her research involved wider subjects, while this research limited its subjects only to those experiencing internship at international ships. This difference might be the reason causing the opposing results.

This result also reveals that all language skills and components receive even distribution in the syllabus used to teach the respondents. With no apparent "lacks" and the results of "necessities" analysis in the previous section, it will be useful to adjust the syllabus in order to prepare future candidates better before conducting their internship. Another option is to leave the syllabus as it is and simply provide the internship candidates with additional learning hours to help them improve their spoken communication skills. This may be a better option as it accommodate the "necessities" of selected candidates without compromising the "necessities" of other students. Another research at Polimarin has come to the 
same conclusion regarding the need to modify the existing syllabus (Marselia \& Hartono, 2017).

\section{Wants}

The next section of the questionnaire gathered information regarding the "wants" aspect. Several components from the syllabus were taken and presented to the respondents to choose to meet their learning preferences. These consisted of learning materials (tenses, grammatical features, and language functions) and learning activities.

Asked about which English tenses were useful to prepare for their internship, all 7 provided options recorded more than $50 \%$. The respondents were given option to add their own option, but no respondent did this. It is worth noted that the top two selected tenses were the simple present tense (89.5\%) and the simple past tense $(94.7 \%)$.

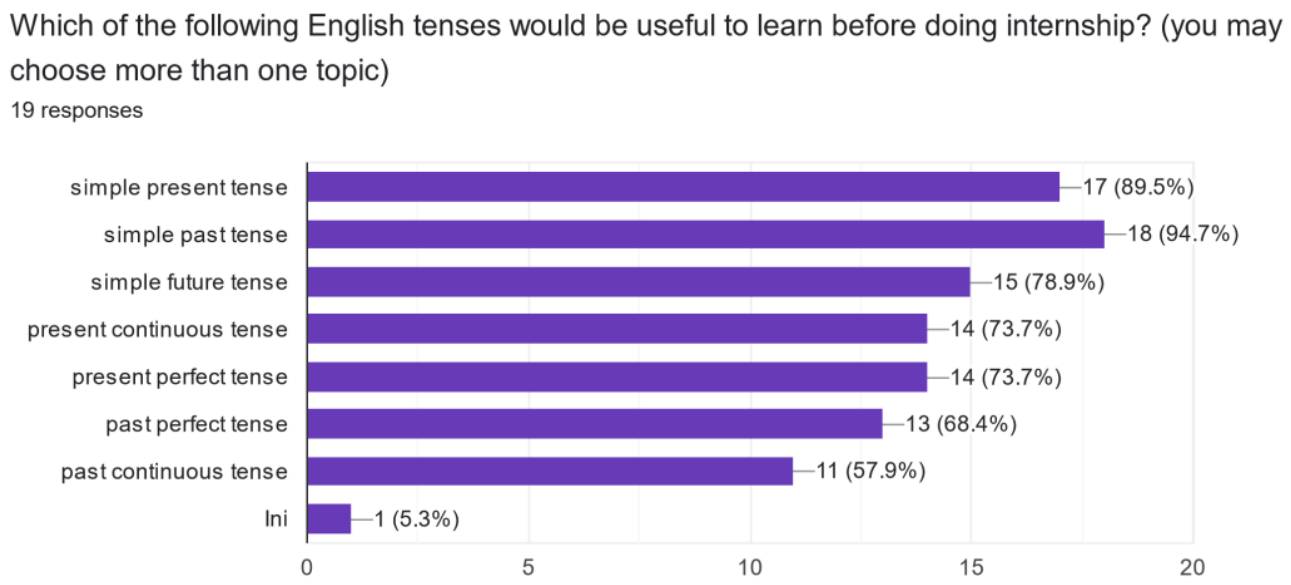

Figure 3. Tenses "Wants" Result

It has been noted that the most used tenses in daily communication is the simple present tense, followed closely by the simple past tense and the simple future 
tense. English has several tenses that could be used to express different time lines (past, present, and future), with various complexity in their grammar. However, people prefers simplicity in their language. Even though a certain idea may be best expressed in a more complicated tense, they tend to tone the tense down to a simpler one. This is even truer for those who are in the stage of learning or acquiring English, such as the respondents in this research.

Other than tenses, the questionnaire also asked about the usefulness of some grammatical features for the internship. There were 11 available options, with another option for the respondents to add their own selected grammatical features. Similar to the previous question, all options received more than $50 \%$ responses, with pronouns $(84.2 \%)$ and conditional sentence $(78.9 \%)$ received the highest number of selections.
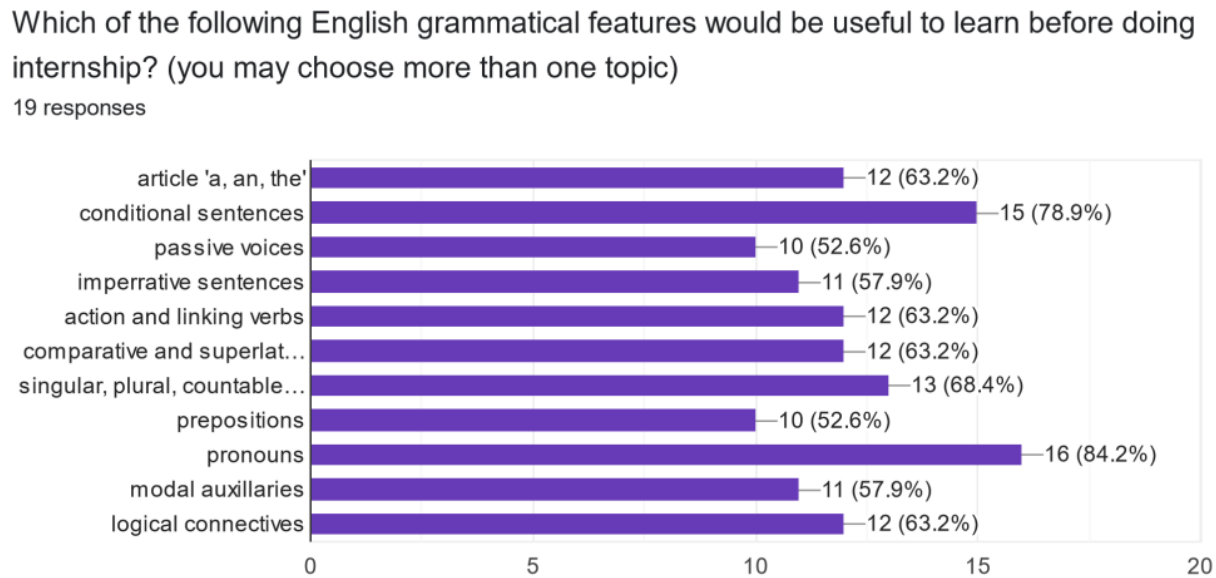

Figure 4. Grammatical Features "Wants" Result

The topic of pronoun is the runaway leader in term of the most wanted option. The simplest sentence consists of at least subject and predicate. In every day communication, sentences very rarely stand alone. They appear in succession with other sentences in order to form a discourse. Here, pronouns play significant role 
as the glue of those sentences. Pronouns make the idea flow fluently between sentences, creating coherent and cohesiveness.

Meanwhile, the topic of "passive voice" is considered as the least important one. It is line with the previous result in the "necessities" section that "grammar" is less needed than "vocabulary". The difference between active and passive voice lies in the verb form and incorrect usage of verb form is often found in English language learner. Therefore, as long as the subject and object are correctly placed, an ungrammatical passive voice can still be understood.

The next question asked about language functions that should be practiced before the internship. All 8 available options also received more than $50 \%$ responses. There were 4 additional options from the respondents. Upon being interviewed for confirmation, 2 out of those 4 additional options actually similar to the ones already provided. Meanwhile, the other 2 additional options referred to the same thing, which was doing test practices in order to pass the internship test.

Which of the following English practices would be useful to learn before doing internship? (you may choose more than one topic)

19 responses

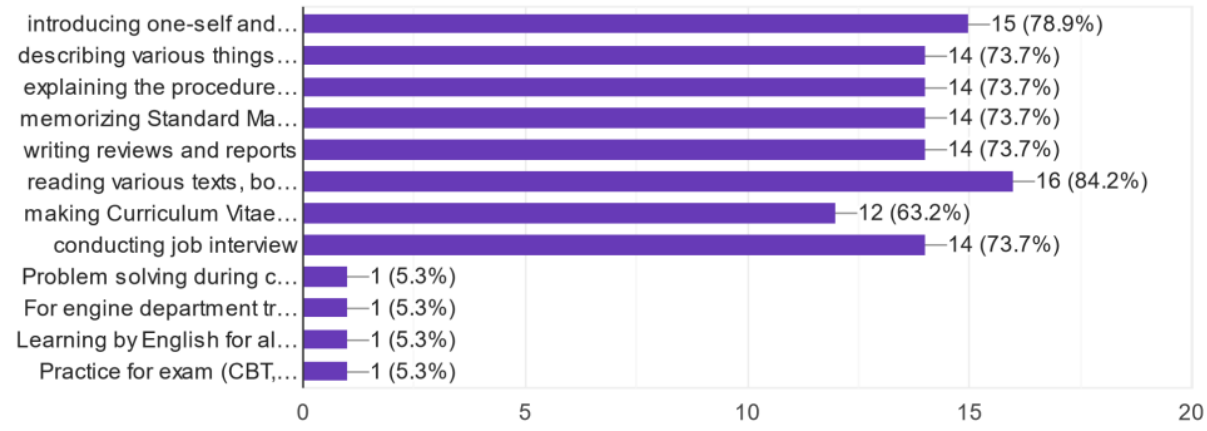

Figure 5. Language Functions "Wants" Result 
It is safe to say that all those language functions are necessary for the respondents to learn. It is revealed that the topic of "curriculum vitae (CV)" received the least number of responses. The reason for this is because they needed CV only for the application. After that, CVs have no use during internship. However, this result cannot be used as the consideration of dropping this topic from the syllabus. Without good CVs, there is a possibility that they will not have the chance to do internship in the first place, making the other language functions useless.

Another point of notice is that 2 respondents provided additional answers to the existing ones. They wanted to practice doing Marlin Test (the entrance test for internship). This TOEFL-like test is designed to assess the candidate proficiency in listening, grammar, vocabulary, time, number, and reading. It is quite noticeable that the test puts less focus on speaking, a skill which is heavily needed in the actual internship. Therefore, further analysis will be needed to see whether the syllabus in Polimarin covers the topics of assessment in the test. Subsequent analysis to see whether the syllabus should be altered to match the test without compromising the general objective of the syllabus may also be required.

The last question was geared toward the type of learning activities opted by the respondents. There were 5 available options, as the most commonly used ones in teaching at Polimarin. Group discussion received the highest number of responses at $94.7 \%$. In addition, there were 4 additional options provided by the respondents. 2 of them were about watching various videos about maritime topics delivered in English. The other 2 wanted to have more chance for practicing speaking. 


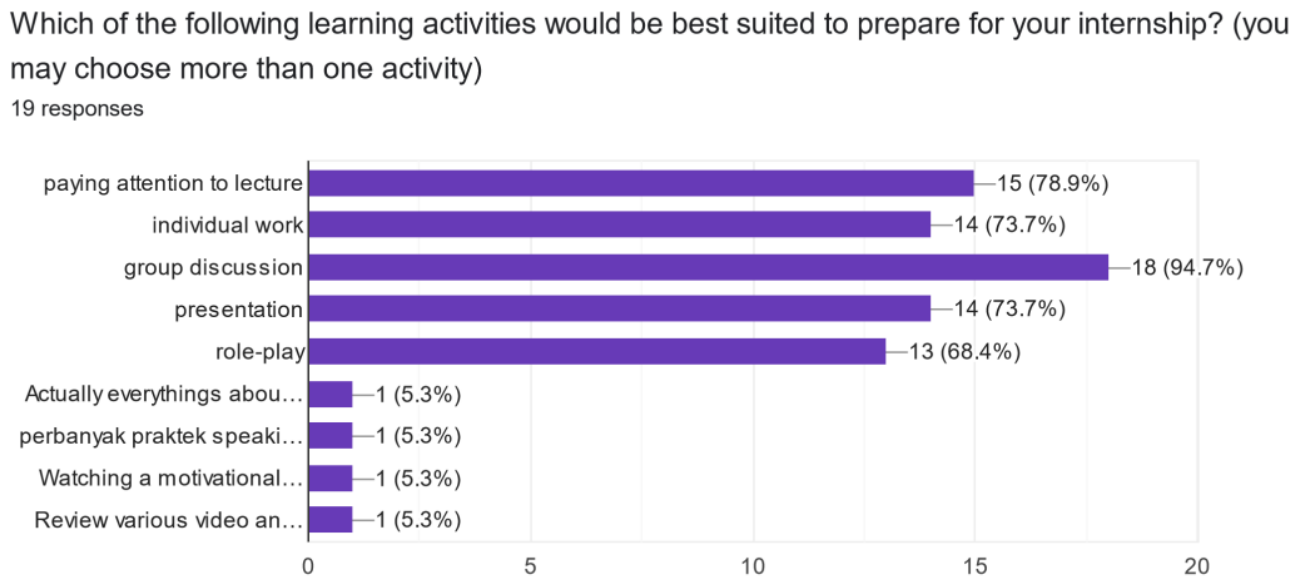

Figure 6. Learning Activities "Wants" Result

Here, the most preferred learning activities is "group discussion". This result is supporting the already discussed one that speaking is very important during internship. Of the 5 available activities, this one is arguably the best in providing real life-like communication. Options "lecturing" and "individual work" are not designed to provide speaking opportunity. "Presentation" does afford them the chance to speak, but it is mostly done one way. Meanwhile, "role play" is not suitable for them as they will only have one role when they are doing internship. The emphasis on speaking is highlighted further by an additional response from two respondents that they should practice speaking all the time, including when they are learning other subjects.

Of the three needs analysis aspects, the "wants" aspect might be the most influencing one in term of raising students' motivation as they have more influence in the decision-making. Moreover, when the "necessities" and "lacks" are the same, different students might have different "wants", let alone students with different "necessities" and lacks". This can be proven by comparing the 
result of this research with another ESP analysis on English for Physics Study (Indrasari, 2016), where "group discussion" is not the most preferred learning activities.

\section{E. CONCLUSION AND SUGGESTION}

\section{Conclusion}

The "necessities" analysis revealed that international maritime sector is heavily reliant on English as the medium for communication. The English spoken skills are more needed compared to the written counterparts due their activities mostly done in spoken manner. Vocabulary also receives more attention than grammar as spoken skills pay more attention to vocabulary. The "lacks" analysis showed that the majority of respondents were prepared well before their internship, even though some felt they could have been prepared better. It also showed that the syllabus used pays attention to English skills and components evenly, rather than directed to spoken skills and vocabulary. Lastly, the "wants" analysis came up with the simple present tense and the simple past tense as the most wanted tenses to master, pronouns as the most wanted grammatical feature and passive voice as the least wanted, all language functions evenly wanted, and group discussion as the most preferred learning activity.

\section{Suggestion}

Further works should be conducted in order to improve English in preparing the students before they take part in the maritime world. Revising syllabus to proportionally meet the students" "necessities", "lacks", and "wants" is suggested as a continuation of this research.

\section{F. ACKNOWLEDGMENT}

The researchers would like to thank the Ministry of Education and Culture, through Polimarin, which has funded this research. 


\section{G. REFERENCES}

Basturkmen, H. (2010). Developing Courses in English for Specific Purposes. In Developing Courses in English for Specific Purposes. Palgrave Macmillan.

Burns, A., \& Joyce, H. (1997). Focus on Speaking. National Centre for English Language Teaching and Research.

Colman, A. M. (2014). A Dictionary of Psychology (Third). Oxford University Press.

Flowerdew, L. (2013). Needs Analysis and Curriculum Development in ESP. In B. Paltridge \& S. Starfield (Eds.), The Handbook of English for Specific Purposes (pp. 301-321). Wiley-Blackwell.

Guritno, S. (2017). Pentingnya Penerapan IMO Resolution A.918 (22) Tentang Standard Marine Communication Phrases Bagi Deck Officer Di Kapal. XVII(1), $1-18$.

Hoesny, M. U. (2013). From Syllabus Design to Curriculum Development. Jurnal Linguistik Terapan, 3(1), 23-50.

Hutchinson, T., \& Waters, A. (1987). English for Specific Purposes: A Learningcentred Approach. Cambridge University Press.

Indrasari, N. (2016). English for Specific Purposes: A Need Analysis at The Second Semester of Physics Education Students of IAIN Raden Intan Lampung in The Academic Year of 2015/2016. English Education: Jurnal Tadris Bahasa Inggris IAIN Raden Intan, 9(1), 161-172.

Kuning, D. S. (2019). Technology in Teaching Speaking Skill. Journal of English Education, Literature and Linguistics, 2(1), 50-59.

Marselia, \& Hartono, R. (2017). The Implementation Of Standard Training, Certification And Watchkeeping 2010 To Redesign The Maritime English Syllabus For Fulfilling Students' Needs. English Education Journal, 7(2), 130138.

Mayers, A. (2005). Gateways to Academic Writing: Effective Sentences, Paragraph, and Essays. Longman.

Mikulecky, B. S. (2011). A Short Course in Teaching Reading: Practical Techniques for Building Reading Power (2nd ed.). Pearson Education ESL. 
Miles, M. B., \& Huberman, A. M. (1994). An Expanded Sourcebook: Qualitative Data Analysis. Sage Publications.

Rahayuningsih, M. (2020). Polimarin Alumni’s English Proficiency in Maritime Industry Competitiveness in Indonesia. IJICC International Journal of Innovation Creativity and Change, 14(12), 1007-1030.

Rahman, H., Satria, A., Iskandar, B. H., Soeboer, D. A., Jenderal, D., Laut, P., Ri, K., Pengajar, S., Ekologi, F., Bogor, I. P., Pengajar, S., Studi, P., \& Perikanan, T. (2017). Determination of the Dominant Factor Cause of Ship Accidents in Tanjung Priok. Albacore, I(3), 277-284.

Rantung, F. (2021). Jumlah Pelaut Indonesia Ketiga Terbesar di Dunia. https://www.idxchannel.com/economics/jumlah-pelaut-indonesia-ketiga-terbesardi-dunia.

Rost, M. (2011). Teaching and Researching Listening (Second). Pearson.

Sebba, M. (1997). Contact Language: Pidgins and Creoles. St. Martin's Press.

Sharifian, R. (2009). English as an International Language: Perspectives and Pedagogical Issues. Multilingual Matters.

Sugiyono. (2016). Metode Penelitian Kuantitatif, Kualitatif, dan R\&D. Alfabeta.

Syahdian, A. (2017). Hubungan Rest Hour Terhadap Kesehatan Dan Keselamatan Kerja Pelaut. Politeknik Ilmu Pelayaran Semarang.

Thornbury, S. (2002). How to Teach Vocabulary. Pearson Education ESL. 